as a whole do not show any tendency to become brighter simply because of the training of their parents.

The second experiment described was one by Dr. I. Krechevsky on "Hypotheses" in rats. Using some of Prof. Tryon's bright and dull strains in a discrimination box which has four successive choices, Dr. Krechevsky has found that the maze-bright rats tend to establish 'spatial' position-habits first, whereas the maze-dull rats tend to establish 'visual' position-habits first. This seems to indicate that Prof. Tryon has been selecting not for an absolute $g$, in Spearman's sense, but for some more specific ability to be called perhaps 'spatial ability'. Dr. Krechevsky's experiment is also theoretically important because it indicates that what in the past were considered as mere blind 'position-habits' in rats have really the properties of 'hypotheses'. They are adopted one at a time and are persevered in or abandoned as they prove to be successful or otherwise.

The third experiment reported was one carried out by Prof. Tolman himself, and is to be regarded as a further analysis of the rat's spatial abilities.
Two food-boxes were used, one reached by a short path, and one by a longer path. After the rats had learned to go very consistently to the nearer of the two boxes, they were put into this box by hand, and received there unexpectedly an electric shock. When they were placed at the starting point immediately afterwards, only some thirty per cent proved sufficiently aware of the relationships involved in that they refused to go towards this box, and took the path to the other box instead. If, however, they were run into the nearer food-box just before receiving the shock in it, practically all of them refused to go to it in an immediately subsequent trial. It appears that the ability to recognise a given path as leading to a given result--in this case an electric shock-is much easier when the actual sequence has been just experienced, than when the sequence has to be inferred, so to speak.

Prof. Tolman also discovered that if the rats found themselves unexpectedly blocked in all directions, they exhibited emotional breakdowns very similar to those reported by Prof. Lewin when working with children and adults in similar situations.

\title{
A National Academy of Sciences for India
}

$\mathrm{I}^{\mathrm{N}}$ our issue of September 23 last, support was given to the movement to establish a national Academy of Sciences in India. Reference was made to the Academy of Sciences of the United Provinces, which its founders hoped might develop into an AllIndia organisation, and to the Asiatic Society of Bengal, which will celebrate its 150th anniversary in January next. There is a strong feeling in India in favour of the formation of a national academy, to represent so far as possible all scientific interests in the country, but difficulties are likely to arise in deciding upon the most suitable centre for the new organisation. We outlined the position in the article already mentioned, and have now received from Dr. S. L. Hora, of the Indian Museum, Calcutta, a copy of twelve resolutions adopted. at a general meoting of men of science in Calcutta held on September 17, and therefore before the issue of NATURE of September 23 reached India. Dr. L. L. Fermor, director of the Geological Survey, seems to have taken a leading part in preparing a constitution for the proposed Academy, and he has been empowered to put the views of Calcutta scientific workers before the Indian Science Congress when it meets at Poona.

We have not space to print the resolutions in full, but the following abridgement represents fairly the views of a large body of men of science in India in support of both the proposal for the foundation of an All-India Academy of Sciences and also upon the claims of Calcutta for recognition as the centre of such an organisation.

In view of the rapid advances that scientific research has made, and continues to make, in India, a Central Body should be organised capable of co-ordinating research, safeguarding the interests of scientific workers, advising both the Central and Provincial Governments regarding the application of scientific methods to ameliorating the condition of the masses and to establishing contact with other International scientific bodies. In view of the above, the proposal for the foundation of an Indian Academy of Sciences was unanimously approved and strongly supported.

All departments of science, both pure and applied, such as Mathematics, Physics, Meteorology, Chem. istry, Geology, Zoology, Botany, Medicine, Anthropology, Psychology, Agriculture, Forest Research, Engineering, Veterinary Research, Geography, etc., should be included in the scope of the Academy and allowed effective representation in the proposed constitution.

The Academy should undertake to encourage scientific research in all its aspects by holding meetings, by publishing results of research of outstanding merit, by providing suitable library facilities, and by such other means as may appear conducive to the advancement of science in India. It should further be the object of the Academy to stimulate research in less-developed sciences and to arrange for provision of equal facilities for research in all the depart. ments of science included in its scope.

The existing scientific bodies in India should be represented on the Academy with a view to ensuring co-ordination of research and the much needed co-operation of all scientific workers in India. This will enable scientific knowledge in the country to be pooled and applied to the practical needs of the nation.

The Academy should be of an All-India nature and represent as far as possible all seientific interests in the country. It should be so designed as to command the greatest respect and influence both in India and in International circles. It was, therefore, considered desirable to associate the new body, when founded, with the Asiatic Society of Bengal. Such an association is desirable for several reasons, such as facilities for meetings offered by this Society, its rich library, its existing relations with outside academies and societies, its influence with the Central and Provincial Governments and, above all, because a strong liaison with the various branches of Letters will thus be preserved, for it is most desirable that Science and Letters should not lose the benefit of healthy intellectual co-operation. 
With a view to bring about intimate relationships between the proposed Academy and the Asiatic Society of Bengal, the Council of the Asiatic Society of Bengal should be requested to modify and alter its constitution so as to provide full scope for the activities of the proposed Academy.

In selecting the original members of this Academy it is desirable to find some formula that will utilise the already recorded opinion of scientists in India. For this reason the past General and Sectional Presidents of the Indian Science Congress resident in India should be invited to form the initial foundation members. In addition, the heads of Central scientific departments and institutes, the Presidents of All-India and Provincial Scientific Societies, with representatives of the Universities, should be included as ex-officio Additional Members. This initial body of members should annually elect not more than 10 new members.

Calcutta is the most suitable place for the location of the proposed Academy in view of its having been a centre of scientific research for more than a century. Further, the presence of a very large number of scientific men in Calcutta, the fact that Calcutta is the seat of various scientific departments and surveys, its unrivalled facilities for research work in the form of libraries and laboratories, its facilities for interchange of thought, its central situation, and above all, the existence in Calcutta of the veteran scientific and literary society of the East, the Asiatic Society of Bengal, are very cogent reasons in support of the Committee's recommendation.

\section{University and Educational Intelligence}

CAMBRIDGE.--The Vice-Chancellor has announced that a donor who wishes to be anonymous has presented the sum of $£ 1,000$ for the furtherance of the work which is being done in the Sub-Department of Experimental Zoology.

Trinity College, Cambridge, has announced its annual offer of a research studentship open to graduates of other universities who propose to go to Cambridge in October next as candidates for the degree of Ph.D. The value of the studentship may be as much as $£ 300$ a year if the pecuniary circumstances of the successful candidate require so large a sum. Applications must reach the Senior Tutor not later than July 1, 1934. The College also offers Dominion and Colonial exhibitions to students of Dominion and Colonial universities who wish to go to Cambridge next October as candidates for the degree of B.A., M.Litt., M.Sc., or Ph.D. These exhibitions are of the titular value of $£ 40$, but their actual value may vary with circumstances. The Council has power, if funds are available, to award additional payment. Candidates must apply through the principal authority of their university, and applications should reach the Senior Tutor (from whom further particulars may be obtained) by July 1, 1934.

The Isaac Newton studentship has been awarded to J. A. Edgar, of Sidney Sussex College.

LIVERPOOL.-The Frazer lecture for 1933 will be delivered by Prof. C. G. Seligmann, professor of ethnology in the University of London, on November 30, who will take as his subject "Egypt and Negro Africa-Divine Kingship".
London.--Mr. and Mrs. C. J. Courtauld have given $£ 25,000$ for the endowment of a "Courtauld Chair of Animal Husbandry".

St. Andrews.--The portrait of Sir James Irvine, vice-chancellor and principal of the University, painted by Mr. Oswald Birley, and the portrait of Dr. E. S. Harkness, of New York, painted by Mr. Frank O. Salisbury, will be received by the Rt. Hon. Stanley Baldwin, chancellor of the University, on behalf of the University, in the Younger Graduation Hall, St. Andrews, on Saturday, November 18, at 5.30 p.m.

SHEFFIELD. - The following appointments have recently been made :-Mr. W. J. Lytle, to be lecturer in surgery; Mr. W. J. Mitchell, to be junior research assistant in glass technology; Mr. H. Laithwaite, to be research fellow in glass technology.

THe Carnegie United Kingdom Trust has agreed to set aside a further sum of $£ 10,000$ for the extension of the new regional library service.

Dr. M. H. MacKeith, dean of the Medical School in the University of Oxford, has been appointed dean of the British Postgraduate Medical School. The foundation stone of the new School, which will adjoin, and be associated with, the London County Council Hospital at Ducane Road, Hammersmith, London, was laid by the Right Hon. Neville Chamberlain, on July 17. It is hoped that the School will be open to students towards the end of 1934 .

DR. D. H. INGALL has been appointed principal of the Borough Polytechnic, in succession to $\mathrm{Mr}$. J. W. Bispham, who has been promoted to Assistant Education Officer (Technology) under the London County Council. In 1919-21 Dr. Ingall was senior lecturer in the Department of Metallurgy of the University of Birmingham; in 1921-28 principal and head of the Department of Metallurgy of the Staffordshire County Technical College, Wednesbury. Since 1931 he has been assistant director and research manager of the British Non-Ferrous Metals Research Association.

IN the Calendar of University College, London, for 1933-34 forty pages are devoted to a programme of post-graduate courses of lectures and arrangements for laboratory work of advanced students in forty. three departments. Conspicuous among these, by reason of the fact that similar opportunities are offered by few, if any, other institutions, are advanced courses in phonetics, Egyptology, the history, methods and principles of science, town-planning, statistics and eugenies. In the Department of Chemical Engineering, a special feature of the first year of post-graduate work is the provision for maintenance of active contact with industry by means of visits to some twenty-five selected works and factories during the session and lectures in the Department by representatives of different industries on Saturday mornings throughout the session; the second year will be devoted entirely, with the excep. tion of occasional lectures on special topics, including the lay-out of factories, administration and economics, to original research in the laboratories or at industrial works. 